\title{
COMMON EYE PROBLEMS IN TROPICS
}

Dr. R. P. Poklurel F. R. C. S.t

Most of the diseases are similar all over the world, but certain diseases are more common in tropical countries io respect to temperate climate possibly due to some climatic likturs, mental attitude and illeteracy. Generally speaking people in the tropics have darker shin ciark brown iris and the most pigmented choroid reflects less light for funduscopy. Pupils in the heavily pigmented dark brown iris is smaller and does not react to ligbt so easily and iends to dilate less and slowly due to thicker hypertropic and highly pigmented iris. Presbyopia also seems to develop earlier in tropics and the average people develop senile cataracts in the carly sixties which is not so in colder climates. In oriental eyes, the filtration angle seems to Wock more readily after glucoma operations and the eyes seem to stand greater rise of intraocular tension without much ill effects.

People in Nepal are poor. Majority of them do come to the hospital very late when the disease is in already advanced stage due to ignorance, illiteracy, poverty, and many a times monsoon blocking the roads and the social custom or rather their mental attitude of going to 'Dhami-Jhankri' (pcople who believe in spirits and spiritual things) having Kaviraj (old Ayurvedic medicines) who are less expensive and are locally available.

It is also difficult to have the proper history from a patient and to plot the peripheraf and central fields in gluroma or in any neurological diseases. Many patients who come with the eye complains do not tell the past history of other illnesses which are very relivant like juint involvements, genital discharges, pulmonary tuberculosis and the past bistory of syphylis or even the important present illness like diabetes mellitus, hypertension, nephritis; endoerine disturbances etc, which they are suffering because they feel it bas got nothing to do with the cyes. Many a times if they have complains in one eye they let you to examine that particular eye and not to touch the other eye which they believe is their perfect eye. Majority of the patients are less desciplined and stop the treatment as soon as they are better and hardly carry out the full course of medicine and if they are no better usually blame for their bad luck

TEyc Sergeon, Bir Hospital, Katbrandu 
rather than the doctors. If they die in the hospital after surgery they feel that the doctor killed them.

The incidence of Amblyopia ( a lazy eye) with Squint seems to be very higb in Nep due to the ignorance of the parents and the less availability of the trained eye specialists. parent do not consult the doctors regarding their children's eyes at their earlier age when it possible to correct easily and to give binocular vision. I have noticed even some qualifit foreign graduate medical doctor feels that the Squint in the right eye of his son is a lucky and does not like to be operated or treated. The incidence of macular degeneration or involvement due to central serous retinopathy, Eclipse burn or some idiopathic cause is bigh in Nepat which needs furthur research and investigations.

Possibly due to heat, dusty atmosphere and the lack of bygine, the incidence trachoma seems to be rather high in tropical countries and in Nepal it is more common the Terai belt and in the people who have lived or visited India for a while. It scems to less common in Kathmandu's local dwellers "Jyapis" community who hardly leave the valk and the hilly people who have never visited the low Terai lands or Indin. In my experience is less common in the hills above the height of $4-5000 \mathrm{ft}$. high.

Traumatic injury both blunt penetrating wounds are common in Nepal and so fat have not seen a single case of Sympathetic Opthalmiti but several case of panophthaimit Corneal ulcers after a scratch by the - leaves of paddy corn is common. I have seen even farmers loosing their eyes because of it. Here I would like to classify some of the comm tropical diseases which can involve the eye and deal few of them which are more common' Nepal in my short experience of 1 year at Bir Hospital and various Eyc camps held 'Dolkha', 'Doti' and 'Lalitput'.

\section{Classification of tropical diseases which cummonly involve eyes}

I. Bacterial:-
1. Tuberculosis.
2. Syphilis,
4. Cholera.
5. Bacillary dysentry.
3. Leprosy.
II. Rubella \& other virus diseases:-
1. Smallpox.
2. Measles.
4. Herpes Zoster.
5. Herpes Simplex.
3. Chicken Pox
6. Mumps.

IIJ. Parasites:-
1. Toxoplasmosis.
2. Amoebiasis.
4. Malaria.
5. Leishmaniasis,
7. Schistomisis.
\& 10. Bancroftian filariasis.
8. Yaws.

3. Loa Loa,

6. Trypanosomiss

9. Onchocerciasil 
1V. Nalnutrition:-

v. Tropical Blindness:-

7. Nutritional Difficiences:

2. Eclipse Burn.

vi. Eye Complications after couching,

VII. Bites and stings of inse

VII. Rhinosperidium Seeberi causing conjunctival polyp.

A jout twu decades back one of the common occular problem in Nepal was the eye nvolvements by smallpox. Blindness in the western world is dut to glaucoma, diabetes, optic atropy, Nepal due to corneal opacity after smallpox, phthisis bulbi after injury; keratome are blind in Neparact; and the majority of them could be helped by corneal $\cdots$ grafting and le and the ca. There are many puor helpless blind people in Nepal who are blind in bol lens ces by snaltpox in the from of complete corneal opacity and few with Phisisis bulbi ater corneal perforation. Thanks to the Public Health Department and the modern living and education that the smallpox is gradually vanishing in most parts of Nepal.

Cutaneous erruption of the licls and catarrhal types of conjunctivitis pustules with secondary intections may extend to the cornea leading to hypopyon ulcer. In neglected cases, the cornea may perforate leading to Phtbisis bulbi.

Eclipse burn of macular region leading to poor sight in one eye also seems to be fairly common in Kathmandu valley and outside Nepal. They are usually detected in the sehool and colleges where they have refractive errors and are unable to read the letters in the blackboard and has to go to the eye surgeon for glasses. Sometimes they are detected wen the individual wants to enter the goverment jobs and comes for routine eye cleck up or sometimes by the specialist in their private clinic, when the patient is still unaware of his poor vision. I have seen at least more tban 100 cases of Eclipse burn within 1 year. Most of them were adult males and very few females. If there is amblyopia or a Squint or if the vision can not be improved by glasses one must exclude the eclipse burn involving the macular or paramacular region by carefuly. funduscopy after clilating both the pupils by Homeatropic ( $2 \%$ ), or Mydrilate." Vitamin deficiency is very common in Nepal but the claisical optic atropy due to nutritional deficiency does not seem to be tbat common in my. expericnee.

Macular involvement due to old patch of choroiditis also seem fairly common in Nepal but we have not carried out any complete survey in this feld. Amoebiasis, Toxoplasmosis, bacillary disentry, tuberculosis and syphilis are still comteon in Nepal and produce various fundus changes. Filariasis is specially common in Kathmandu valley and so far I have.- 
detected only one worm in the A. G. of one patient .- an ocular thread worm.

Leprosy is fairly common in Kathmandu valley and outside Nepal and I feel ono cat hardly see elsewhere such an advanced cases involving both the eyes with complete blindnet Both tuberculoid and lepromatous type are common. Lagoptbalmos due to involement of $t$ nerve supply of orbicularis muscle commonly causes drying of the cornea with exposure kefe titis later leading to scaring of the cornea and loss of vision. Secondary infection may leat tọ Hypopyon ulcer, panophalmitis, secondary glucoma, iris prolapse and phthisis bulbi. Fal ing of eye lashes with tuberculoid batch on the skin of the eye led is also seen.

The common picture which is more often seen is the actual infiltration by the lepros becilli into the tissues of the globe. Early picture ofsuperficial Punctate keratitis, episclerity or mild iritis is less often seen. I have often seen the advanced case of granulomatous iridoej litis and the dark brown noduls as big as the sago grain involving the whole of the which one can easily see by naked eyes with proper illuminations. Some time one can see nodules filling the whole of $\mathrm{A}$. C, with large mutton fat $\mathrm{K}$. P. on the posterior surface the cornea but the eye is still quite witb no ciliary congestions. Many patients are blind both their eyes due to compicated cataract secondary to uneitis. 



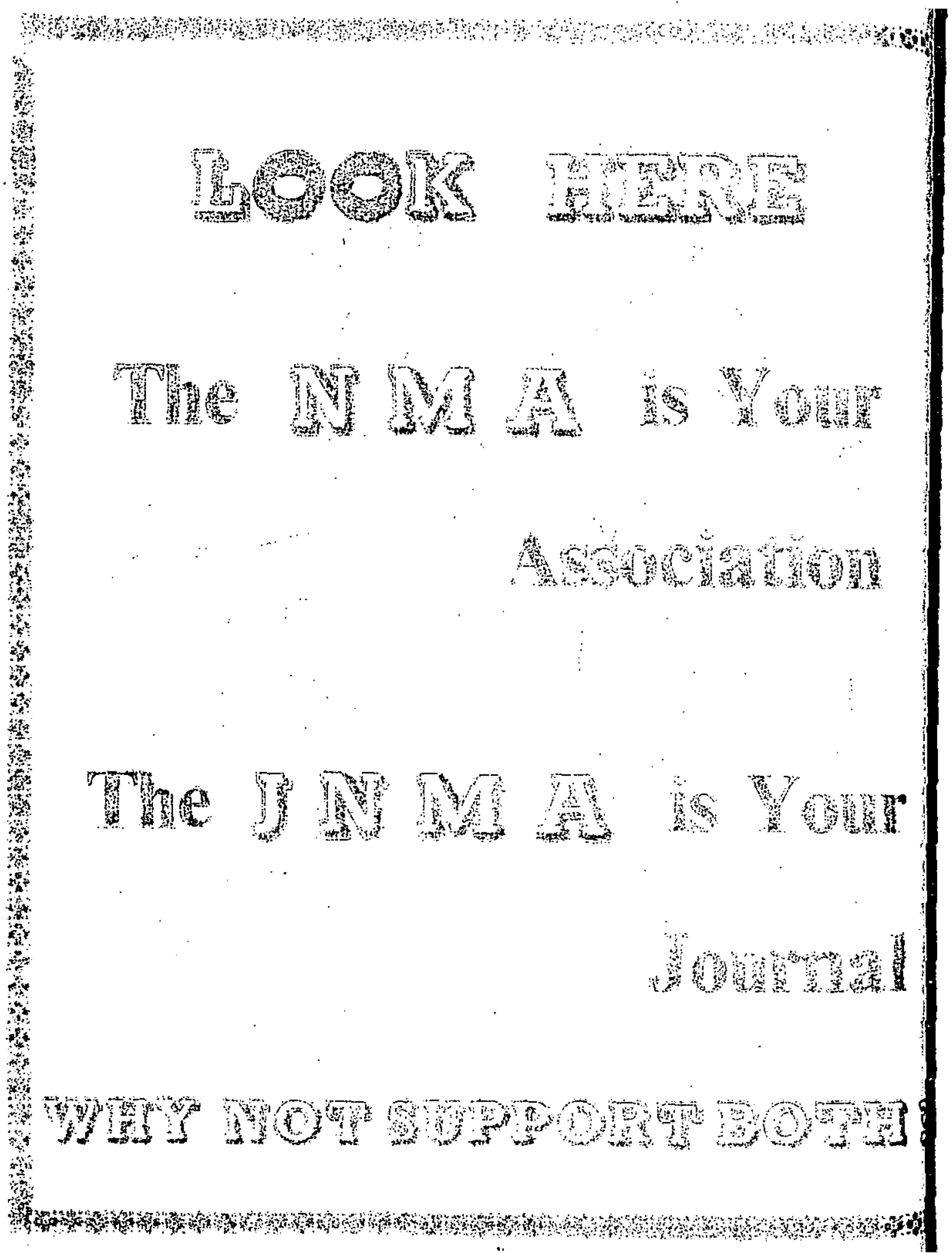

